Int. J. Curr. Res. Med. Sci. (2017). 3(8): 58-64

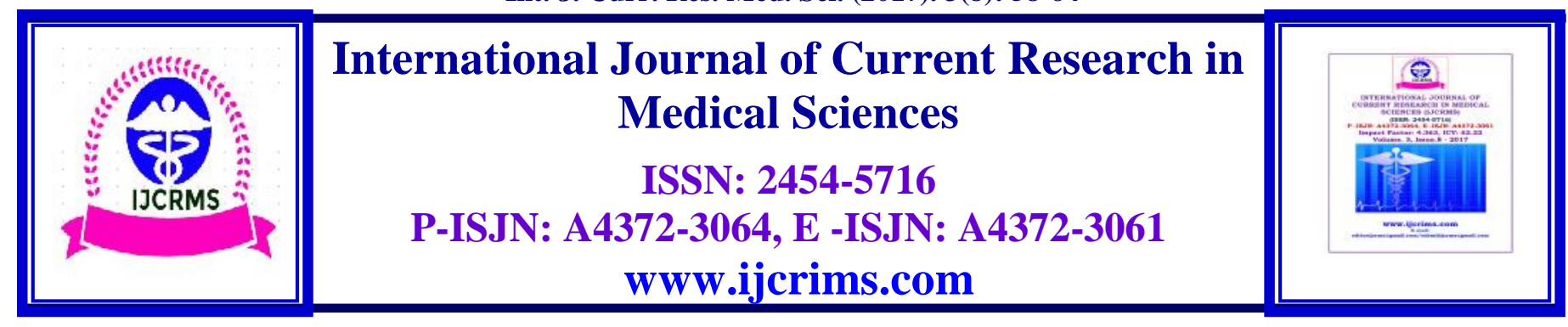

\title{
Retrospective Autopsy Study of Custodial Deaths in Rajindra Hospital (GMC) Patiala
}

\author{
*DS Bhullar; **Kulbhushan Garg; ***KK Aggarwal; \\ ***** Charan Kamal Ladhar \\ * Assistant Professor; ** Senior Resident; *** Professor \& Head; **** Junior Resident. \\ Department of Forensic Medicine \& Toxicology, \\ Government Medical College \& Rajindra Hospital Patiala- 147001 (Punjab) India \\ Corresponding Author: Dr. DS Bhullar, Assistant Professor, Department of Forensic Medicine \& \\ Toxicology, Government Medical College Patiala - 147001 (Punjab) India \\ E-Mail:drdsbhullar@yahoo.in
}

\begin{abstract}
Custodial death in police or jail custody is a well known cause of suspicion of foul play against authorities concerned and needs thorough investigation under law including autopsy study. Although unnatural causes of custodial deaths point towards torture or maltreatment by the custodians of the case, natural causes of custodial deaths also need to be investigated to gauge the parameters of treatment being given to the ill. The present study was conducted to analyze the pattern of deaths of custodial cases of Rajindra Hospital attached to Government Medical College Patiala from January 2015 to June 2017 and included only 40 cases excluding some in which the required chemical and histopathological investigations were pending. Year wise number of cases was almost similar. Maximum deaths occurred in the age groups of 21 to 40 years and above 60 years of age with male predominance and almost all deaths from natural causes except three cases which included ante-mortem hanging in jail and police custody and one case of accidental choking of a male child. The study indicates absence of adequate and timely medical treatment of the ill jail inmates with suggestions to explore the reasons behind such high mortality and morbidity so that remedial measures are taken and human rights of custodial cases protected.
\end{abstract}

Keywords: Custodial Death, Autopsy, Histopathological Investigation, Hanging, Choking, Human Rights Commission 


\section{Introduction}

Custodial death means death of a person being provided protective supervision. A person may die in jail or police custody or during police interrogation or police firing. Inquiry to ascertain certain matters of fact in such cases is conducted by a magistrate with intention to ensure that no person is unjustly deprived of his liberty and his rights as a citizen, no person who is deprived of his liberty can die as a result of neglect or brutality by the people in whose charge he is and in case of a person who is already buried, if there is any doubt as regards identity, cause of death, or manner of death, it will be settled by a judicial inquest and not a police inquest [1]. During the Australian Royal Commission into Aboriginal Deaths in Custody (1991), the issue that whether some deaths actually occurred in custody surfaced glaringly. The Royal Commission recommended that a 'death in custody' should, at least include the following circumstances of death:

- $\quad$ Those occurring in prison or while in police custody.

Those caused or contributed to by traumatic injuries sustained, or due to lack of proper care, while in custody or detention.

Those in which the fatal injury resulted from police or prison authorities attempting to detain a person.

Those in which a fatal injury resulted on a person escaping or attempting to escape from police custody or juvenile detention.

The Human Rights Commission of India, constituted under The Protection of Human Rights Act 1993, for better protection of human rights and for matters connected therewith or incidental thereto, necessitates reporting of custodial deaths within 24 hours and to conduct a postmortem examination by a board of doctors including video filming of the procedure and this speaks of the gravity of concern of the Commission [2]. However, as a general observation, most of the custodial death cases indicated outcome of a natural disease and hence, it was decided also to assess the actual situation about custodial death cases being dealt in Rajindra Hospital under Government Medical College Patiala in the Punjab state of India.

\section{Materials and Methods}

Government Medical College Patiala is a leading tertiary care institute of northwest India that caters to the health and medico-legal issues of the population in this region. The present retrospective autopsy study was conducted for the period from January 2015 to June 2017 on the custodial death cases brought for postmortem examination in the mortuary of Rajindra Hospital Patiala under the department of Forensic Medicine and Toxicology of this medical college and included a total of 40 cases admitted in this hospital for various conditions and died.

These cases belonged to the local jail or were referred to this hospital from other jails of the region directly or indirectly through the local jail and represented mainly the prison population only. Their dead bodies were subjected to medico-legal autopsy as required by Indian laws on requisition by the judicial magistrates. The data were collected from the post-mortem records, medical records, police inquest reports, histopathological examination and toxicological records of the cases. The data thus collected was subsequently analyzed and compared with other national and international studies.

\section{Results and Observations}

Table No. 1: Year-Wise Distribution of Cases

\begin{tabular}{|l|c|c|}
\hline \multicolumn{1}{|c|}{ Year } & Number of Cases & $\%$ Age \\
\hline 2015 & 19 & 47.5 \\
\hline 2016 & 15 & 37.5 \\
\hline $2017: 6$ months & 6 & 15.0 \\
\hline
\end{tabular}


The number of custodial death cases reported during the study period was 19 in the year 2015, 15 in 2016 and 6 in the first six months in the year 2017 with an average of more than one case per month which means every month one or two custodial deaths are taking place in the jails being catered by Rajindra Hospital Patiala for the treatment and medico legal purpose.

Table No. 2: Age-Wise Distribution of Cases

\begin{tabular}{|l|c|c|}
\hline \multicolumn{1}{|c|}{ Age in Years } & Number of Cases & \% Age \\
\hline $0-20$ & 05 & 12.5 \\
\hline $21-40$ & 14 & 35.0 \\
\hline $41-60$ & 08 & 20.0 \\
\hline Above 60 & 13 & 32.5 \\
\hline
\end{tabular}

In the present study, maximum deaths occurred in the age group of 21 to 40 years $(35.0 \%)$ followed by age group of above sixty years $(32.5 \%)$ with age group of minimum deaths 0 to 20 years
(12.5\%). The custodial deaths of younger generation, may be from any reason, is a cause of grave concern for the authorities and requires urgent attention.

Table No. 3: Sex-Wise Distribution of Cases

\begin{tabular}{|l|c|c|}
\hline \multicolumn{1}{|c|}{ Sex } & Number of Cases & $\%$ Age \\
\hline Male & 37 & 92.5 \\
\hline Female & 3 & 7.5 \\
\hline
\end{tabular}

More than 90 percent cases of custodial deaths were males with male to female ratio as 12.33: 1.00 , meaning the number of male cases was 12 times more compared to female cases. This means custodial death population mainly includes male persons.

\section{Table No. 4: Natural / Unnatural Type of Cases}

\begin{tabular}{|l|c|c|}
\hline \multicolumn{1}{|c|}{ Type of the Cases } & Number of Cases & \% Age \\
\hline Natural & 37 & 92.5 \\
\hline Unnatural & 03 & 7.5 \\
\hline
\end{tabular}

Except three cases in which the cause of death was unnatural, all others cases were of deaths from natural causes including diseased condition of different body organs or systems. It led to the conclusion that custodial deaths from natural causes are 12 times compared to unnatural causes. The unnatural causes in the present study included hanging in jail and police custody in two cases and one death of a two years old minor male child due to asphyxia from accidental choking from excessive breast feeding by the convict mother who was not mentally sound and was on antipsychotic medication. 
Int. J. Curr. Res. Med. Sci. (2017). 3(8): 58-64

Table No. 5: Disease -Wise Distribution of Cases of Natural Causes

\begin{tabular}{|l|c|c|}
\hline \multicolumn{1}{|c|}{ Name of the Organ / Disease } & Number of Cases & \%age \\
\hline Heart & 4 & 10.8 \\
\hline Lungs & 4 & 10.8 \\
\hline Liver & 2 & 5.4 \\
\hline Kidneys & 1 & 2.7 \\
\hline Multiple Organs & 17 & 45.9 \\
\hline Septicemic Shock & 1 & 2.7 \\
\hline Others & 5 & 13.5 \\
\hline Opinion not possible & 1 & 2.7 \\
\hline Reports awaited & 2 & 5.4 \\
\hline
\end{tabular}

In case of deaths due to natural causes, about 46 percent cases included multi-organ failure from one or the other reason, about 11 percent deaths included single organs heart and lung failure and in one case the opinion about cause of death could not be given due to negative chemical and histopathological examination results which otherwise was a suspected case of poisoning from postmortem findings. The different ailments included myocardial infarction, brain hemorrhage, Pulmonary Koch's and other lung diseases, renal failure from different causes, septicemia, dehydration, carcinoma of rectum and breast, alcoholic and drug induced liver failure, hepatitis, complications of different diseases in organs and HIV AIDS in one case.

\section{Discussion}

Death in custody often arouses public interest and may lead to volatile emotions in the family or friends, media and general public and needs effective investigation and handling especially under alleged allegations of ill-treatment shown by the custodians of the case. The assessment about the accidental, homicidal, suicidal or purely natural cause of death is based on meticulous postmortem examination along with thorough investigation of the surrounding circumstances leading to death. This may invite the skill and experience of various experts for satisfactory conclusions required to clear the air or sometimes confirm allegations of some act of commission or omission on the part of the custodians that had led to or contributed to the death.

In the present study, more than 40 custodial death cases were dealt with for postmortem examination in the Government Medical College Patiala with an average of one or two cases every month. In a similar study conducted in this institute from January 2010 to December 2013, the total number of custodial death autopsies recorded was 60 in four years with almost similar incidence of the cases in comparison with the present study [3].

Maximum deaths in the present study occurred in the age group of 21 to 40 years $(35.0 \%)$ followed by age group of above sixty years $(32.5 \%)$ with age group of minimum deaths 0 to 20 years ( $12.5 \%)$. The custodial deaths of young generation of 21 to 40 years may be from any reason, is a cause of grave concern for the authorities and requires urgent attention. The proportion of deaths in the present study was near to the earlier study in this age group [3] but there was a shift in the age group of above 60 years from 10 percent to 32.5 percent which means the death rate rose to three times in the above 60 age group cases during the period under study and this shift is required to be investigated separately to check the mortality and morbidity of this age group as the life expectancy of Indian males has gone above 68 years as per the latest national surveys and the older generation should not die in jails from unchecked ailments. 
More than 90 percent cases of custodial deaths were males with male to female ratio as 12.33 : 1.00 in this study, meaning the number of male cases was 12 times more compared to female cases and custodial death population mainly includes male persons. This observation is consistent with other studies in India [3, 4, 5] and other developed countries like Australia [6, 7, 8] USA [9], UK [10, 11, 12] and Canada [13]. The greater number of male custodial deaths world over suggests that male population is much more involved in different kind of criminal activities and consequently to be present in large numbers in jails. According to National Crime Records Bureau, Prison Statics India 2015, out of a total of 1584 deaths in jails reported in the year 2015, only 51 were female inmates and the rest 1533 were male inmates indicating very high custodial male mortality compared to females [14].

All cases except three in this study were of deaths from natural causes including diseased condition of different body organs or system indicating custodial deaths from natural causes is 12 times compared to unnatural causes. The unnatural causes in the present study included hanging in jail and police custody in two cases and one death of a two years old minor male child due to asphyxia from accidental choking from excessive breast feeding by the convict mother who was not mentally sound and was on antipsychotic medication. Nearly half of the deaths from natural causes included multiple organ failure from different ailments and in one case the postmortem findings suggested death due to poisoning but no conclusive opinion could be formed due to negative chemical and histopathological reports. Only one case was diagnosed as death due to Acquired Immune Deficiency Syndrome in the present study. Multi-organ failure in majority of the natural deaths in the present study indicates lack of timely intervention to diagnose the disease of a particular organ and system which led to the involvement of other organs resulting in complications.

Overcrowding has become a serious problem for the correctional administration in India. There are about 1276 prisons with accommodation capacity of 2.8 lakh, however the total number of inmates is around 4 lakh [14]. Overcrowding has serious impacts on prisoners' health. The deleterious effect of overcrowding on prisoners' health is evident from the fact that the skin and other infectious diseases tend to grow [15]. Prisoners have poor sanitary conditions; the ratio of latrines to prisoners is very low. If in the cell then they are required to answer the call of nature in pots kept in the cell, making the atmosphere stinky and extremely unhygienic. Thus prisoners bear a substantial burden of infections, physical and mental disorders as compared to general population [16]. All of this take a toll on inmates' health and can be a strong reason of prisoners' morbidity and mortality.

A study in Andhra Pradesh, India revealed the tragic story of denial of treatment to its prisoners leading to a rise in deaths of inmates under custody [17]. The same study cited lack of quick medical attention as one of the most important reason for prison deaths. A prisoner is referred to the hospital only on being too critical and the process is so long that the prisoner dies before even reaching the hospital. And the irony is that the government knows about this fact about prison deaths are increasing due to a lack of timely police escort.

\section{Conclusion and Limitations}

1. There is urgent and dire need for improvement in the medical care facilities in the state institutes dealing with custodial cases which primarily are state prisons.

2. The prisoners are required to be sensitized to bring to the notice of prison authorities including prison officers, officials and the medical staff any ailment or bodily problem immediately for timely intervention and treatment.

3. Proper hygienic conditions and atmosphere needs to be provided to the inmates with preventive purpose.

4. The jail medical staff should be quick to respond to the medical issues of the inmates.

5. Overcrowding problem which may be one of the primary causes of infectious diseases needs to be addressed on priority. 
6. There should be regular inspections of the prisons for satisfactory medical aid provisions and there should be a mandatory provision of medico-clinical investigation in each natural custodial death with focus on how to decrease the morbidity and mortality in these cases.

7. Senior citizens in prisons need extraordinary medical care and treatment for their ailments.

8. Separate wards need to be created to segregate custodial patients suffering from communicable ailments.

The present study represents a general picture of prison fatalities in this region of the country as it included only the cases which were brought for postmortem examination only in this particular health institute. We do not advocate being soft on the prisoners but we insist on human and sensitive treatment to this section of society because everyone has the right to life and so does a prisoner.

\section{Source of funding: Nil}

\section{Conflict of interest: None declared}

\section{References}

1. Parikh C.K. Parikh's Text Book of Medical Jurisprudence and Toxicology; Fifth Edition 1995; p. 10-11.

2. Vij K. Textbook of Forensic Medicine and Toxicology, Principles and Practice; Fifth Edition 2011; p. 191,

3. Singh SP, Singh D, Aggarwal AD, Oberoi SS, Aggarwal KK . Profile of Disease Related Deaths in Custodial Cases: An Autopsy Based Experience J. Indian Acad Forensic Med 2015 Oct-Dec; 37 (4): 392-3.

4. Bansal YS, Murali G, Singh D. Custodial Deaths- An overview of the prevailing healthcare scenario. J Indian Acad Forensic Med 2010; 32(4):315-7.

5. Sonar V. A retrospective study of prison deaths in western Maharashtra (2001-2008). Medico-Legal update 2010; 10(2):112-3.
6. Kariminia A, Law MG, Butler TG, Corben SP, Levy MH, Kaldor JM, Grant L et al. Factors associated with mortality in a cohort of Australian prisoners. Eur. J Epidemiol. 2007; 22(7):417-28.

7. Collins L, Mouzos J. Deaths in custody.A gender-specific analysis. Trends and issues in crime and criminal justice, Australian Institute of Criminology. 2002 Sept [cited 2013 June 2]; 238:1- 6.Available from: http://www.aic.gov.au.

8. Petschel K, Gall JA. A profile of deaths in custody in Victoria, 1991-96. J Clinc. Forensic Med 2000; 7(2):82-7.

9. Kim S, Ting A, Puisis M, Rodriguez S, Benson R, Mennella C, Davis F et al. Deaths in the Cook County Jail: 10 year report, 19952004. J Urban Health 2007; 84(1):70-84.

10. Statistical Analysis of all recorded deaths of individuals detained in state custody between 1 January 2000 and 31 December 2010. Independent Advisory Panel on Deaths in Custody. 2011 Oct [cited 2013 Aug 29]:1-17. Available from http://iapdeathsincustody. independent.gov.uk/wp-content/uploads/ 2011/10/IAP-Statistical-Analysis-of-AllRecorded-Deaths-in-State-Custody-Between2000-and-2010.pdf.

11. Learning from PPO investigations: Natural cause deaths in prison custody 2007-2010. Prisons and Probation Ombudsman, Ashley House, London 2012. [cited 2013 Aug 21]: 118. Available from http://www.ppo.gov.uk/ docs/learning_from_ppo_investigations natural_cause_deaths_in_prison_custody.pdf

12. Farrell M, Marsden J. Acute risk of drugrelated death among newly released prisoners in England and Wales. Addiction 2008; 103(2):251-5.

13. Wobeser WL, Datema J, Bechard B, Ford P. Causes of death among people in custody in Ontario,1990-1999. CMAJ 2002; 167(10):1109-13. 
14. Prison Statics India: National Crime Records Bureau Ministry of Home Affairs Government of India (2015): Kumar, S. D., Kumar, S. A, Pattankar, J. V, Reddy, S. B., \& Dhar, M. Health status of the prisoners in a Central Jail of South India. Indian Journal of Psychological Medicine 2013; 35(4): 373-7. doi:10.4103/0253- 7176.122230

15. Omaar R, Mendez J, Jones S, Laber J, Whitley A . Prison Conditions in India: Human Rights Watch. (1991); p. 23.

16. Fazel, S, Baillargeon, J. The health of prisoners. Lancet 2011; 377(9769): 956-65. doi:10.1016/S0140- 6736(10)61053-7

17. Karnam, M.: Deaths in Prisons in Andhra Pradesh. Economic and Political Weekly.2009 ;44(11): 19-23.

\begin{tabular}{|c|l|}
\hline \multicolumn{2}{|c|}{ Access this Article in Online } \\
\hline & Website: \\
\hline & www.ijcrims.com \\
\hline Quick Response Code & Subject: \\
\hline
\end{tabular}

How to cite this article:

DS Bhullar; Kulbhushan Garg; KK Aggarwal; Charan Kamal Ladhar. (2017). Retrospective Autopsy Study of Custodial Deaths in Rajindra Hospital (GMC) Patiala. Int. J. Curr. Res. Med. Sci. 3(8): 58-64. DOI: http://dx.doi.org/10.22192/ijcrms.2017.03.08.010 